\title{
Silica nanoparticles inhibit ATP responses of human airway epithelial 16HBE cells
}

\author{
Alina Milici ${ }^{1}$, Alicia Sanchez ${ }^{1,2}$ and Karel Talavera ${ }^{1, *}$ \\ 1 Laboratory of Ion Channel Research, Department of Cellular and Molecular Medicine. KU Leuven; VIB \\ Center for Brain \& Disease Research, Leuven, Belgium \\ 2 Current affiliation: Bioclinica GmbH, Munich, Germany \\ * Correspondence: karel.talavera@kuleuven.be; Tel.: 003216330469
}

\begin{abstract}
Because of their low cost and easy production silica nanoparticles (NPs) are amply used in multiple manufactures as anti-caking, densifying and hydrophobic agents. However, this has increased the exposure levels of the general population and has raised concerns about possible toxicity of this nanomaterial. NPs are known to affect the function of the airway epithelium, but the biochemical pathways targeted by these particles remain largely unknown. Here we investigated the effects of NPs on the responses of cultured human bronchial epithelial (16HBE) cells to the damage-associated molecular pattern ATP, using fluorometric measurements of intracellular $\mathrm{Ca}^{2+}$ concentration. Upon stimulation with extracellular ATP these cells displayed a concentration-dependent increase in intracellular $\mathrm{Ca}^{2+}$, which was mediated by release from intracellular stores. Silica NPs inhibited the $\mathrm{Ca}^{2+}$ responses to ATP within minutes of application and at low micromolar concentrations, which are significantly faster and more potent than those previously reported for the induction of cellular toxicity and pro-inflammatory responses. NPs-induced inhibition appeared to be independent from the increase in intracellular $\mathrm{Ca}^{2+}$ they produce, and via a non-competitive mechanism. These findings suggest that NPs reduce the ability of airway epithelial cells to mount ATP-dependent protective responses such as the increase in mucociliary clearance and cough.
\end{abstract}

Keywords: silica; nanoparticles; ATP; purinergic receptor; airway; epithelial cell

\section{Introduction}

Nanoparticles designate small-sized natural or engineered particulate matter with dimensions of less than $100 \mathrm{~nm}$ in at least one dimension, for which physical and chemical properties differ from those of the bulk material. They are composed by a wide range of materials, such as metals, inorganic carbon, and organic compounds. In the last decades, nanoparticles gained popularity in many industries, as their unique properties make them suitable for being used in cosmetics, biotechnology, food, pharmaceutical and chemical industries [1][2][3][4][5][6][7].

Human exposure to nanoparticles increased considerably since the nano-technological revolution. The small dimensions and unique physico-chemical properties facilitate the ability of nanoparticles to cross different barriers and to reach distal organs [8][9][10][11][12]. They can penetrate the plasma membrane and deposit into subcellular structures such as mitochondria, endoplasmic reticulum and lysosomes, thereby posing potential health threats [13][14][15][16][17]. This, together with their extensive use in consumer products raised concerns about the safety of nanoparticles [8][18]. A growing body of evidence points towards the deleterious effects of nanocompounds [9][19][20][21][22]. However, not all nanoparticles are harmful and some of them are engineered to be used in medicine as drug nanocarriers due to the specific interaction with target organs [6][23]. Nanoparticles can enter our bodies by inhalation, ingestion, 
injection or through the skin, but the main entry route is the airway epithelium [8][24]. Besides its role in gas exchange, the airway epithelium protects the body from foreign substances. The cells lining up the respiratory tract have key roles in mucociliary clearance and contribute to the initiation of airway inflammation [25][26][27][28]. In the airways, nanoparticles may interact with epithelial cells and alter their exocrine and paracrine functions and with sensory neurons, which initiate the cough reflex and neurogenic inflammation [29]. It has been shown that upon inhalation, nanoparticles impair the normal functioning of the airways by inducing inflammation, increasing the secretion of mucus and inhibiting the ciliary beat frequency [30][31][32][33][34].

Amorphous silica particles (NPs), the subject of this study, are among the most produced synthetic nanomaterials worldwide due to their tunable physico-chemical properties, stability, low cost and easy production [7][35][36]. NPs have been shown to induce lung inflammation, cytotoxic responses such as apoptosis, DNA damage, endoplasmic reticulum stress, they increase the reactive oxygen species (ROS) production by altering $\mathrm{Ca}^{2+}$ homeostasis, disrupt the plasma membrane upon uptake and alter membrane fluidity and integrity [7][10][15][20][21][37][38]. Previous studies indicate that the effects induced by NPs are size- and concentration-dependent and differ across cell types. More pronounced toxic effects have been reported for smaller particles, increased doses and prolonged exposure times [7][15][39]. Despite the extensive research on NPs toxicity, the mechanisms underlying their deleterious effects are poorly understood. For instance, most of the studies related to NPs are focused on chronic effects for in vitro exposure times ranging from several hours up to days [40]. On the other hand, recent research has illustrated the importance of studying also the acute interaction of NPs with specific cellular structures and signaling pathways. For instance, NP-induced modulation in the time scales of seconds and minutes have been reported for cation-permeable channels that play crucial roles in cell signaling [30][37][39][41][42]. In this sense, ATP-mediated signaling is considered to be involved in inflammatory responses to NPs in multiple cell types [43][44][45][46][47][48].

ATP receptors are ligand-gated cation channels (P2X, ionotropic) or G protein-coupled receptors (P2Y, metobotropic) [49][50][51][52]. Activation of P2X receptors leads to extracellular $\mathrm{Ca}^{2+}$ influx, resulting in plasma membrane depolarization and direct increase in intracellular $\left[\mathrm{Ca}^{2+}\right]$. In contrast, activation of P2Y receptors activates inositol triphosphate $\left(\mathrm{IP}_{3}\right)$-mediated signaling, which opens $\mathrm{IP}_{3}$ receptor $\mathrm{Ca}^{2+}$ channels in the membrane of endoplasmic reticulum (ER), leading to $\mathrm{Ca}^{2+}$ release from these stores [50][53]. In the airways, extracellular ATP signals tissue damage induced by particulates or pathogens, and is therefore considered as a damage associated molecular pattern (DAMP) [54]. ATP receptors are expressed along the respiratory tract in epithelial cells and in sensory nerves in upper (trigeminal ganglia) and lower airways (nodose and dorsal root ganglia). It has been reported that these types of cells express P2X, as well as P2Y receptors. However, airway injury induced by particulate matter inhalation has been predominantly associated to P2Y-mediated signaling in epithelial cells leading to enhanced mucociliary clearance. On the other hand, P2X receptors have a prominent role in sensory nerves, as their activation triggers defensive responses such as cough [54][55][56][57][58][59][60]. Most of the studies addressing ATP-mediated signaling are related to ATP release upon cell damage [61].

The purpose of this study was to determine whether NPs affect the responses of airway epithelial cells to ATP. Using cultured human bronchial epithelial (16HBE) cells as model, we found that acute extracellular application of commercially available NPs potently reduces the responses to ATP in a concentration-dependent manner. Our results unveil the ATP signaling pathway as a direct cellular target of NPs. In the broad context, this suggests that NPs affect the ability of airway epithelial cells to respond to environmental and endogenous stimuli that require ATP-mediated signaling.

\section{Results}




\subsection{Intracellular $\mathrm{Ca}^{2+}$ response of $16 \mathrm{HBE}$ cells to extracellular ATP}

We first characterized the response of 16HBE (16HBE14o-) cells to extracellular application of ATP. We determined the amplitude of the increase in intracellular $\mathrm{Ca}^{2+}$ concentrations induced by three consecutive applications of ATP, at various concentrations (from 0.3 to $100 \mu \mathrm{M}$; Figure 1a-c). The responses very commonly showed a sharp initial upstroke phase, followed by a slow decrease in $\left[\mathrm{Ca}^{2+}\right]_{\mathrm{i}}$, typical of the activation of ATP receptors [62]. As expected, the response in intracellular $\left[\mathrm{Ca}^{2+}\right]$ was concentration-dependent (Figure 1d).
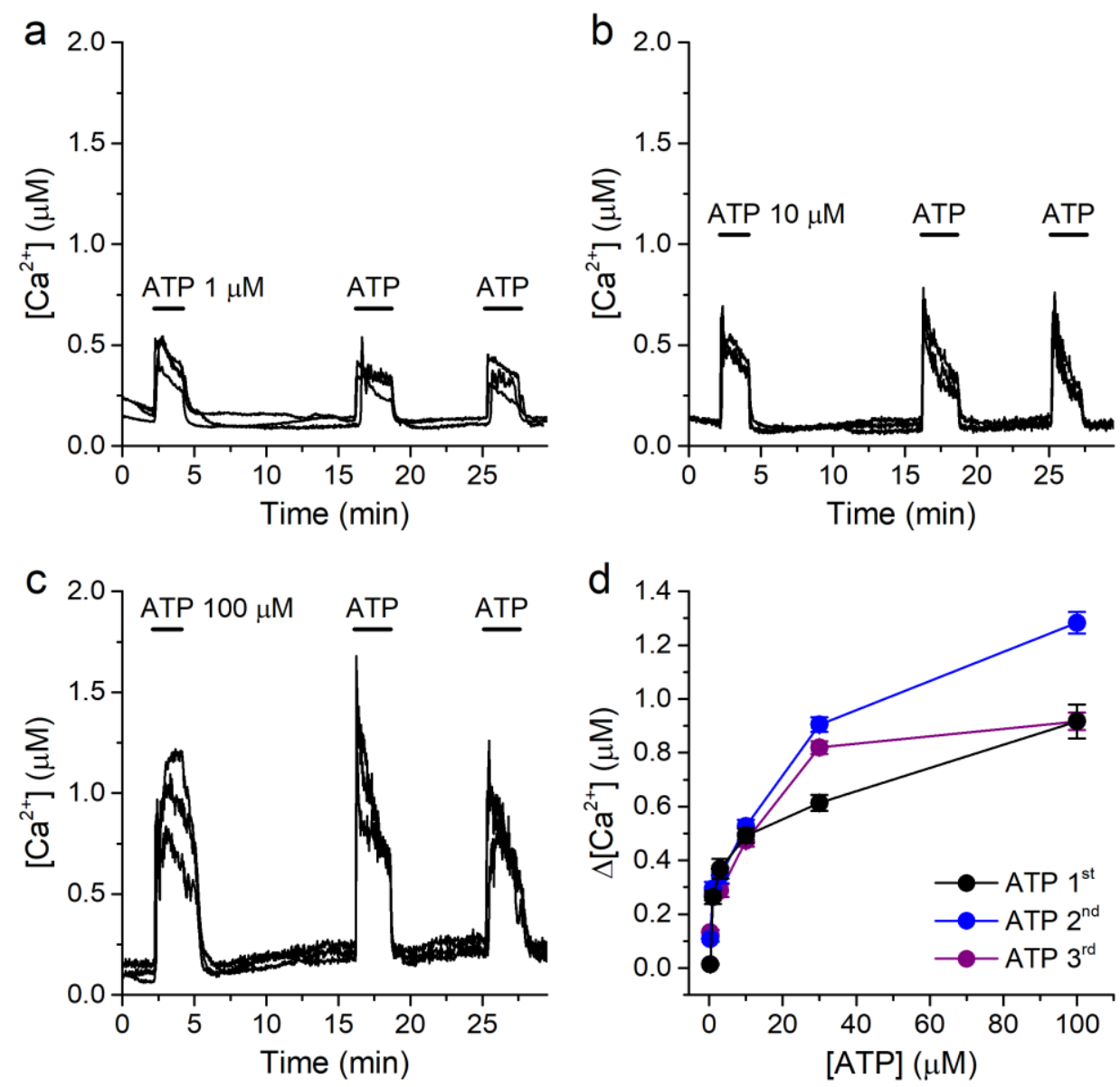

Figure 1. Extracellular ATP induces concentration-dependent responses in 16HBE cells. $(\mathbf{a}, \mathbf{b}, \mathbf{c})$ Examples of intracellular $\left[\mathrm{Ca}^{2+}\right]$ traces showing the responses to extracellular ATP applied at $1 \mu \mathrm{M}(\mathbf{a}), 10 \mu \mathrm{M}(\mathbf{b})$ or $100 \mu \mathrm{M}$ (c). (d) Concentration dependence of the amplitude of the responses to the $1^{\text {st }}$ (black), $2^{\text {nd }}$ (blue) and $3^{\text {rd }}$ (purple) applications of ATP. The data are represented as mean \pm s.e.m. ( $\mathrm{n}=179,59,75,96,278$ and 128 , for ATP $0.3,1,3,10,30$ and $100 \mu \mathrm{M}$, respectively).

Importantly, we found that this type of stimulation protocol allowed us to evoke consecutive responses to ATP in a reliable manner, with no sign of desensitization. Thus, we could use a variant of this protocol to determine whether NPs affect the responses to ATP, by comparing the amplitudes of the responses to ATP in the absence and in the presence of NPs in the same cells.

\subsection{The $\mathrm{Ca}^{2+}$ responses to ATP are mediated by release from intracellular stores}

The intracellular $\mathrm{Ca}^{2+}$ responses to ATP may be mediated by metabotropic (P2Y) and/or by ionotropic $(\mathrm{P} 2 \mathrm{X})$ receptors. To determine the origin of the $\mathrm{Ca}^{2+}$ raise upon ATP application in our experimental conditions we performed measurements in the absence of extracellular $\mathrm{Ca}^{2+}$. For this, cells were allowed to stabilize in the standard Krebs solution before the experiments and then perfused with a $\mathrm{Ca}^{2+}$-free extracellular solution. In the latter condition, a first application of $10 \mu \mathrm{M}$ ATP elicited sizeable intracellular $\mathrm{Ca}^{2+}$ 
responses, whose amplitudes were no significantly different from the amplitudes of the responses recorded in the presence of extracellular $\mathrm{Ca}^{2+}$ (Figure 2a and 2c-left, columns ATP $\left.1^{\text {st }}\right)$. In contrast, the second ATP application induced a transient increase in intracellular $\left[\mathrm{Ca}^{2+}\right]$ only in a very limited number of cells (Figure $2 \mathrm{a}$ and $2 \mathrm{~b}$-left, columns ATP $2^{\text {nd }}$ ) and a third application failed to trigger any response (Figure $2 \mathrm{a}$ and $2 \mathrm{~b}$-left, columns $\operatorname{ATP} 3^{\text {rd }}$.
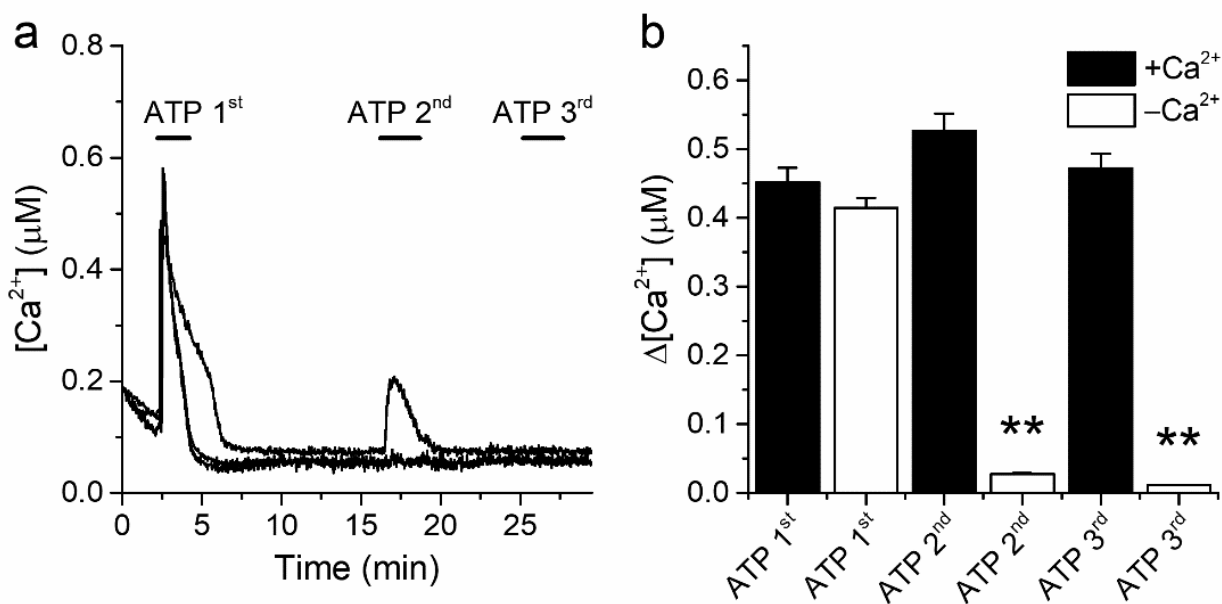

Figure 2. ATP mobilizes $\mathrm{Ca}^{2+}$ from intracellular stores. (a) Examples of traces of $\left[\mathrm{Ca}^{2+}\right] \mathrm{rec}-$ orded in 16HBE cells showing the effects of repetitive extracellular application of $10 \mu \mathrm{M}$ ATP in the absence of extracellular $\mathrm{Ca}^{2+}$. (b) Amplitude of the responses to the $1^{\text {st }}, 2^{\text {nd }}$ and $3^{\text {rd }}$ ATP applications in the presence and in the absence of extracellular $\mathrm{Ca}^{2+}$. The data are represented as mean \pm s.e.m. (n $=207,482,97,249,97$ and 247 for the columns from left to right). The asterisks denote statistically significant difference of the data obtained in the $\mathrm{Ca}^{2+}$-free condition $\left(-\mathrm{Ca}^{2+}\right)$ with respect to the corresponding control data $\left(+\mathrm{Ca}^{2+}\right)$, with $\mathrm{P}<0.01$ (Kolmogorov-Smirnov test).

These results show that $16 \mathrm{HBE}$ cells can support full-sized responses at least to a first application of ATP in the absence of extracellular $\mathrm{Ca}^{2+}$. This demonstrates that the responses are mediated by release from intracellular stores.

\subsection{Concentration-dependent inhibition of responses to ATP by NPs}

To determine if NPs alter the response to ATP we used the same protocol described for Figure 1, but perfusing NPs 7 min prior and during the second stimulation with 10 $\mu \mathrm{M}$ ATP (Figure 3a, b, c). NPs were applied at several concentrations $(1,3$, 10, or 100 $\mu \mathrm{g} / \mathrm{ml})$. To quantify the effects of NPs we determined the ratio between the amplitudes of the responses to the second or third application of ATP and the amplitude of the responses to the first application of ATP. Notably, NPs increased the baseline $\left[\mathrm{Ca}^{2+}\right]$ prior to the second ATP application. The increase in $\left[\mathrm{Ca}^{2+}\right]$ induced by NPs appeared not to be reversible after washout of the nanoparticles for at least the next 9 min of duration of the experiment (Figure 3a-c). This effect of NPs is in accordance with our previous study [30]. NPs reduced the amplitude of responses to ATP in a concentration-dependent manner. The amplitude of second response to ATP was not significantly affected during the application of $1 \mu \mathrm{g} / \mathrm{ml}$ NPs (Figure 3a, d), but was reduced at higher concentrations (Figure $3 b-d)$. The inhibitory effect of NPs was more pronounced on the third ATP application, after the removal of the particles from the extracellular solution (Figure 3d). 

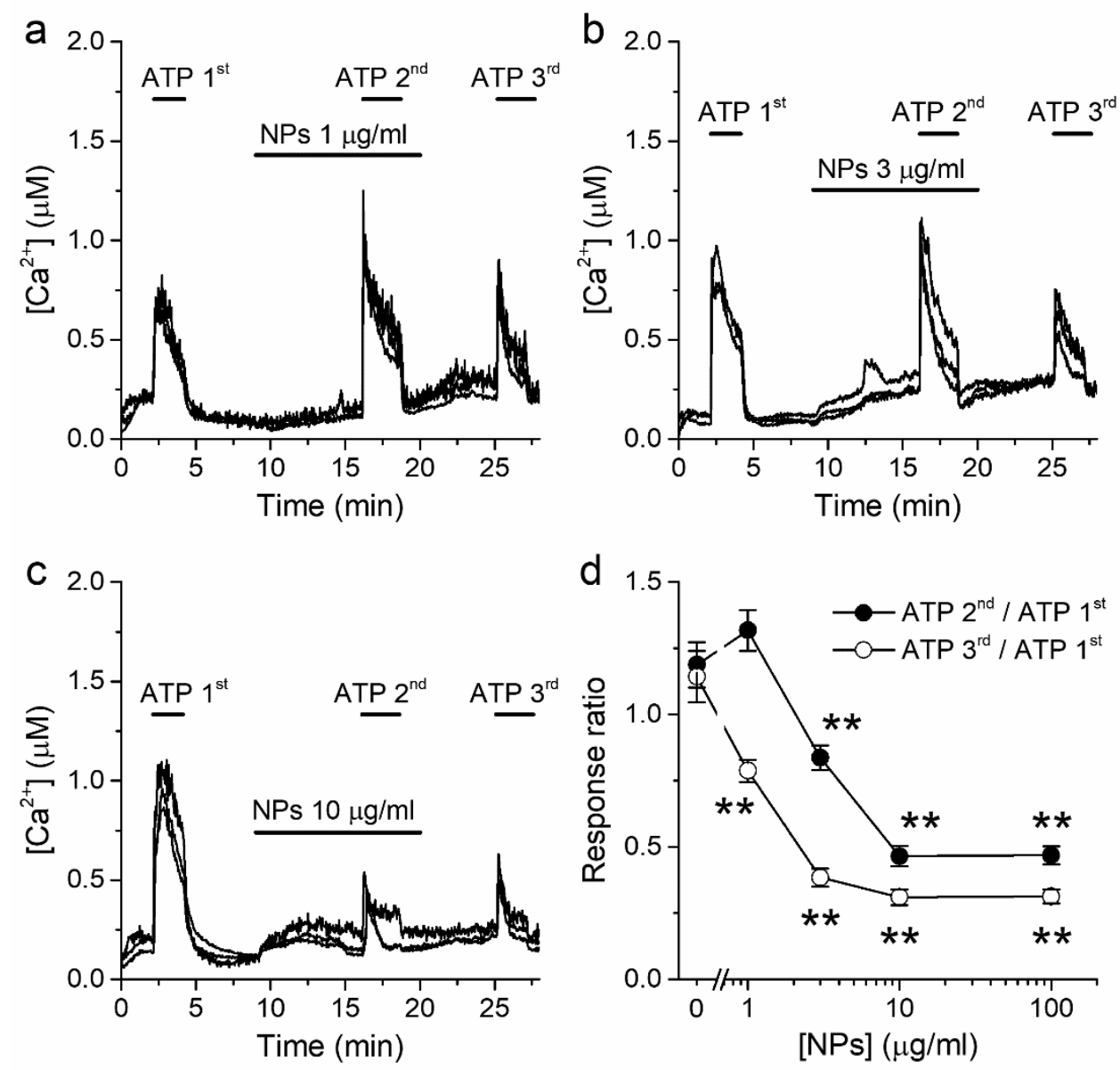

Figure 3. NPs induce a concentration-dependent inhibition on the response to ATP. $(a, b, c)$ Examples of intracellular $\left[\mathrm{Ca}^{2+}\right]$ traces showing the effects of silica NPs when applied at $1 \mu \mathrm{g} / \mathrm{ml}(\mathbf{a})$, $3 \mu \mathrm{g} / \mathrm{ml}$ (b) or $10 \mu \mathrm{g} / \mathrm{ml}$ (c), before and during the second application of $10 \mu \mathrm{M}$ ATP. (d) Ratio between the amplitudes of the responses to the $2^{\text {nd }}$ and $3^{\text {rd }}$ applications of ATP and the amplitude of the response to the $1^{\text {st }}$ application of ATP, as a function of the concentration of silica NPs. The data are represented as mean \pm s.e.m. $(n=135,135,52$ and 92 , for NPs at $1,3,10$ and $100 \mu \mathrm{g} / \mathrm{ml}$, respectively. The asterisks denote statistically significant difference with respect to the corresponding control data $[\mathrm{NPs}]=0 \mu \mathrm{g} / \mathrm{ml}$, with $\mathrm{P}<0.01$ (Kolmogorov-Smirnov test).

\subsection{Effects of intracellular $\mathrm{Ca}^{2+}$ overload on the responses to ATP}

NPs induce on their own an increase in $\left[\mathrm{Ca}^{2+}\right]$ that, in turn, could lead to inhibition of the response to ATP. As a way to assess this possibility we tested whether an increase in $\left[\mathrm{Ca}^{2+}\right]$ induced by a distinct mechanism has a similar inhibitory effect on the responses to ATP. We did this by perfusing the cells with the $\mathrm{Ca}^{2+}$ ionophore ionomycin $(1 \mu \mathrm{M})$. A series of parallel control experiments showed that consecutive ATP applications triggered sizeable intracellular $\mathrm{Ca}^{2+}$ responses (Figure $4 \mathrm{a}$ and $4 \mathrm{c}$, black bars). As expected, ionomycin induced a fast and robust increase in $\left[\mathrm{Ca}^{2+}\right]$, which was in fact much larger than that induced by NPs (Figure 4b,d). In contrast to the increase observed with the NPs, application of ATP during the perfusion of ionomycin did elicit an additional increase in [ $\mathrm{Ca}^{2+}$ ] (Figure $4 \mathrm{~b}$ ). The amplitudes of these responses were not significantly different from the amplitudes observed in the control experiments (Figure 4c). We did observe, however, that the responses to ATP developed more slowly in the presence of ionomycin than in control condition (Figure $4 \mathrm{~b}$ ). This effect was not further characterized. The response to the third application of ATP appeared to be affected by the prior treatment with ionomycin (Figure $4 b, c$ ), but nevertheless this effect was smaller than that caused by 100 $\mu \mathrm{g} / \mathrm{ml}$ NPs (see data for ATP $10 \mu \mathrm{M}$ in Figure 2d). 

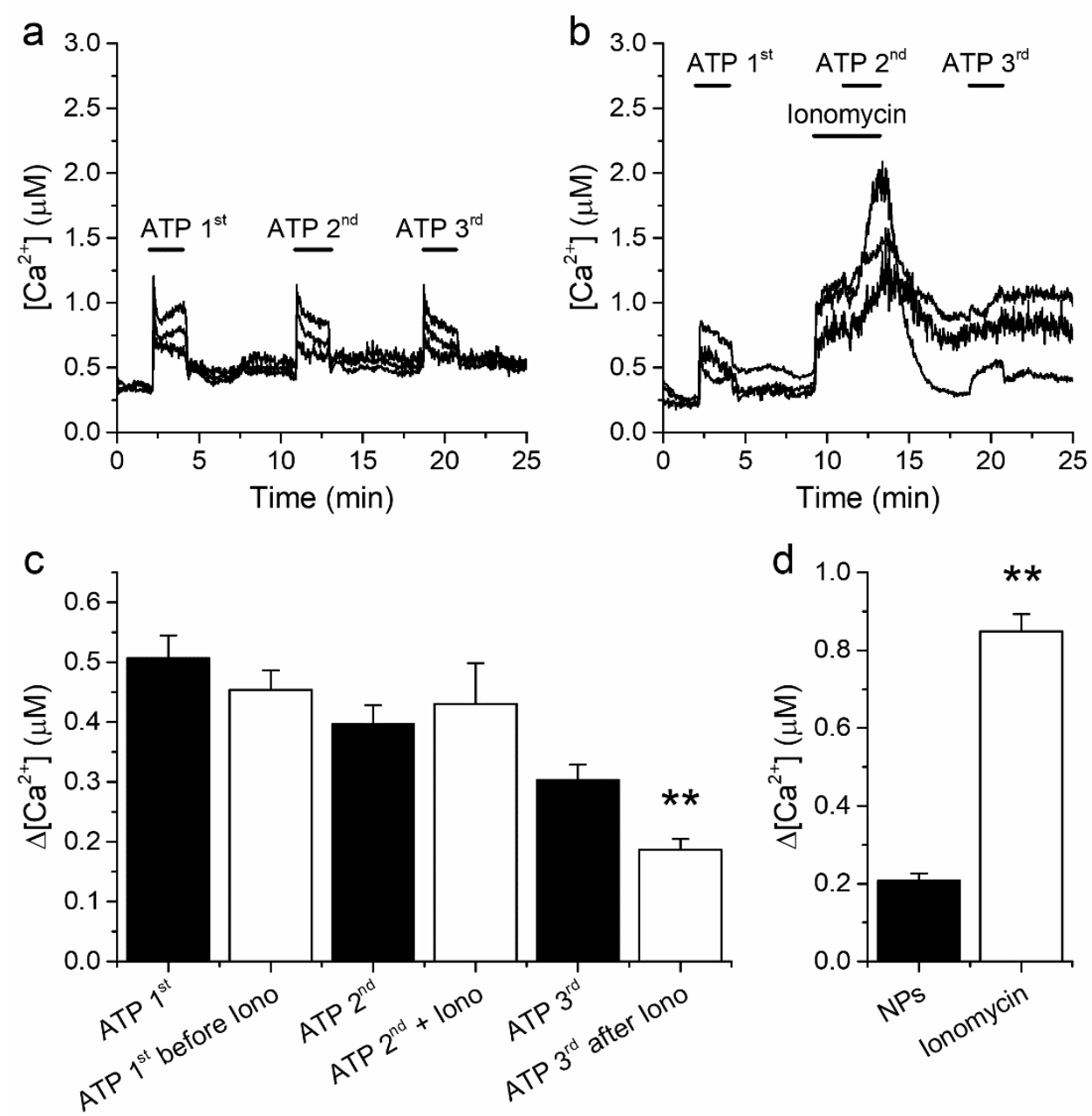

Figure 4. Response to ATP in 16HBE cells overloaded with $\mathrm{Ca}^{2+}$. (a) Example of control $\left[\mathrm{Ca}^{2+}\right]$ traces recorded in $16 \mathrm{HBE}$ cells showing the responses to repetitive extracellular application of $10 \mu \mathrm{M}$ ATP. (b) Examples of traces showing the effects of $1 \mu \mathrm{M}$ ionomicin when applied before and during the second application of $10 \mu \mathrm{M}$ ATP. (c) Amplitude of the responses to three consecutive applications of ATP for the control series of experiments (black bars, $n=36$ ) and for a series of experiments in which $1 \mu \mathrm{M}$ ionomycin was applied $2 \mathrm{~min}$ before and during the second application of ATP (white bars, $n=42$ ). The data are represented as mean \pm s.e.m. The asterisks denote statistically significant difference between ATP $3^{\text {rd }}$ and ATP $3^{\text {rd }}$ after ionomycin, with $\mathrm{P}<0.01$ (Kolmogorov-Smirnov test). (d) Comparison of the amplitude of the $\left[\mathrm{Ca}^{2+}\right]$ responses induced by $100 \mu \mathrm{g} / \mathrm{ml}$ silica NPs and by $1 \mu \mathrm{M}$ ionomycin ( $\mathrm{n}=92$ and 42 , respectively). The data are represented as mean \pm s.e.m. The asterisks denote statistically significant difference between the two bars, with $\mathrm{P}<0.01$ (Kolmogorov-Smirnov test).

\subsection{Effects of NPs on the concentration-dependence of the response to ATP}

Finally, in order to gain insight on the mechanism of action of NPs we determined how they alter the concentration dependency of the response to ATP. For this we used the same ATP application protocol described above (Figure 1), but perfusing $100 \mu \mathrm{g} / \mathrm{ml}$ NPs 7 min prior and during the second stimulation with ATP. We confirmed the responses to ATP to be significantly inhibited in the presence of NPs (Figure 5a-d), and that the response to the third application of ATP was also inhibited, further demonstrating that NPs have an inhibitory effect even after they were removed from the extracellular solution (Figure 5a-d). 

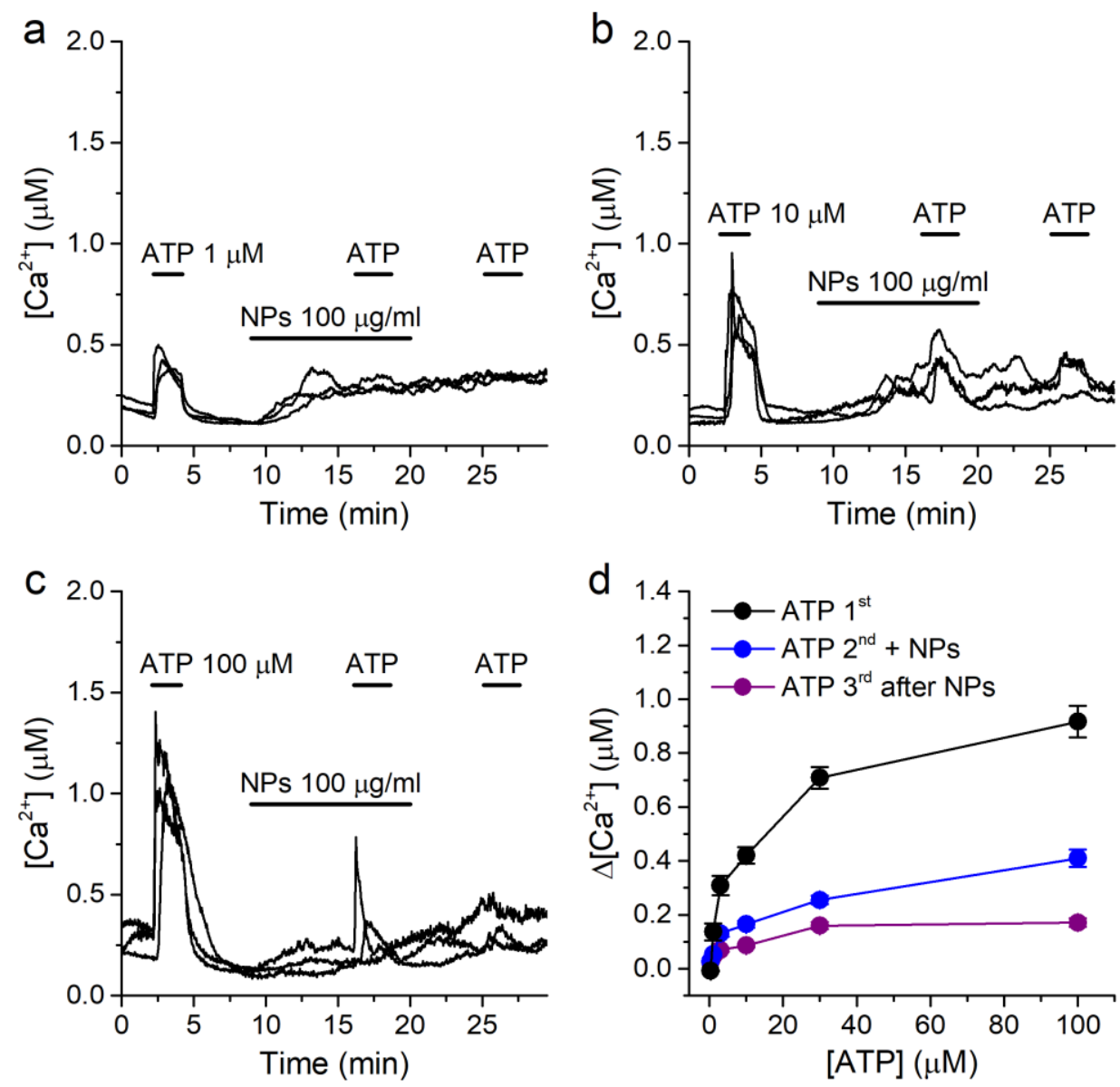

Figure 5. Effects of NPs on the concentration dependency of the response to ATP. (a,b,c) Examples of intracellular [ $\mathrm{Ca}^{2+}$ ] traces showing the effects of $100 \mu \mathrm{g} / \mathrm{ml} \mathrm{NPs}$ on the responses to extracellular ATP applied at $1 \mu \mathrm{M}(\mathbf{a}), 10 \mu \mathrm{M}$ (b) or $100 \mu \mathrm{M}$ (c). (d) Concentration dependence of the amplitude of the responses to ATP, for the $1^{\text {st }}$ (control), $2^{\text {nd }}$ (in the presence of NPs) and $3^{\text {rd }}$ (after washout of NPs) applications. The data are represented as mean \pm s.e.m. ( $n=213,68,130,109,169$ and 146, for ATP $0.3,1,3,10,30$ and $100 \mu \mathrm{M}$, respectively).

By comparing the data shown in Figure $5 d$ with those of Figure $1 d$, it can be noticed that, apart from the obvious differences in maximal values, the shapes of the concentration dependencies determined in the absence and in the presence of $100 \mu \mathrm{g} / \mathrm{ml} \mathrm{NPs} \mathrm{ap}$ peared to be similar. To test whether this was indeed the case we replotted the data by normalizing each curve to the respective value obtained at ATP $100 \mu \mathrm{M}$ (Figure 6a, b). The comparison of the normalized curves revealed a large overlap of the data obtained in the presence and during washout of the NPs with the respective normalized control curves. Finally, we represented these data as Lineweaver-Burk plots $\left(1 / \Delta\left[\mathrm{Ca}^{2+}\right]\right.$ vs. $1 /[$ ATP]) and fitted them with linear functions (Figure $6 c, d$ ). The fits yielded linear functions with slopes that were different between control $\left(2.45 \pm 0.11\right.$ and $2.08 \pm 0.24$ for $2^{\text {nd }}$ and $3^{\text {rd }}$ ATP applications, respectively) and NPs (9.92 \pm 0.9 and $12.9 \pm 3.3$ and for $2^{\text {nd }}$ and $3^{\text {rd }}$ ATP applications, respectively). In contrast, the resulting intercepts with the 1/[ATP] axis, which relate to the inverse of the apparent equilibrium constant $\left(-1 / \mathrm{KM}_{\mathrm{M}}\right)$, were nearly identical for control and NPs conditions ( $2^{\text {nd }}$ ATP application: $-0.44 \pm 0.08 \mu \mathrm{M}^{-1}$ and $-0.47 \pm$ $0.17 \mu \mathrm{M}^{-1}$, respectively and $3^{\text {rd }}$ ATP application: $-0.52 \pm 0.08 \mu \mathrm{M}^{-1}$ and $-0.52 \pm 0.21 \mu \mathrm{M}^{-1}$, respectively). The corresponding $K_{M}$ values for the $2^{\text {nd }} \mathrm{ATP}$ application are therefore: 2.27 $\pm 0.4 \mu \mathrm{M}$ and $2.2 \pm 0.8 \mu \mathrm{M}$ for control and NPs, respectively, and for the $3^{\text {rd }}$ ATP application $1.9 \pm 0.3 \mu \mathrm{M}$ and $1.9 \pm 0.8 \mu \mathrm{M}$ for control and NPs, respectively. This analysis shows that the NPs only decreased the maximal response (efficacy) and not the sensitivity to ATP, suggesting that they have a non-competitive inhibitory action. 
a

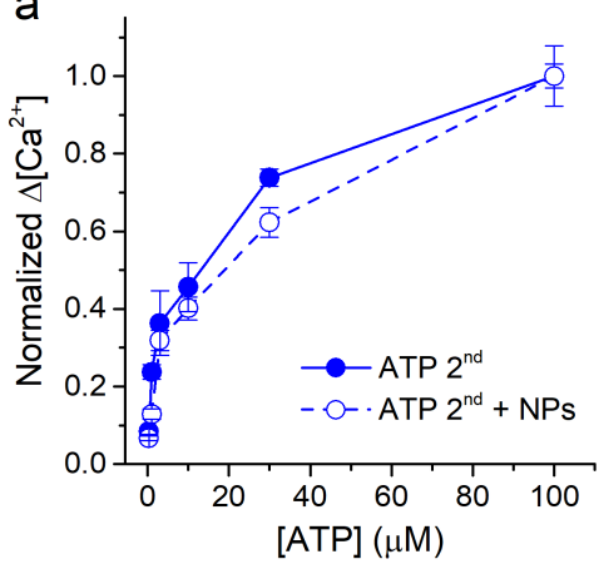

C

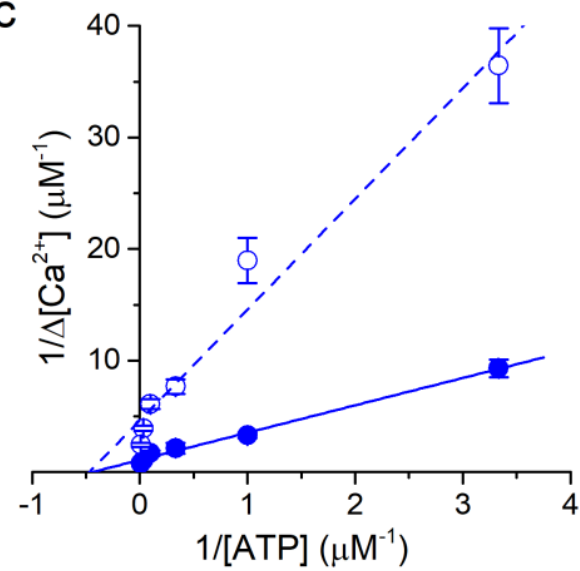

b

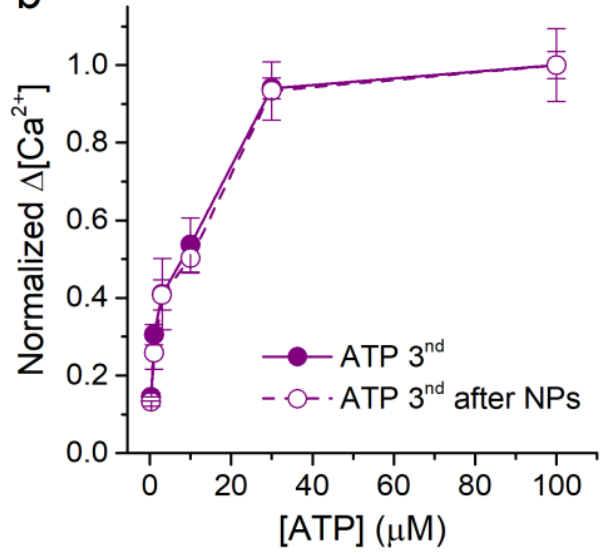

d

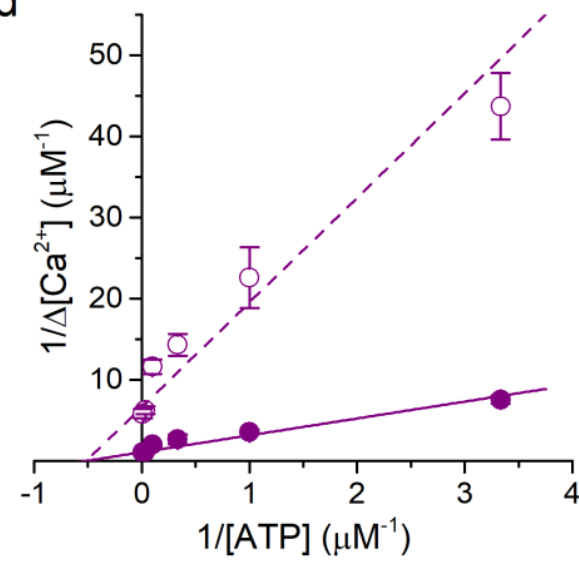

Figure 6. Non-competitive inhibitory effect of NPs on the response to ATP. (a,b) Normalized concentration dependence of the amplitude of the responses to ATP, for the $2^{\text {nd }}$ application (control and in the presence of NPs) and for the $3^{\text {rd }}$ application (control and after washout of NPs). The normalization was performed by dividing the data sets of Figures $1 \mathrm{~d}$ and $5 \mathrm{~d}$ by the corresponding values obtained for $100 \mu \mathrm{M}$ ATP. (c,d) Lineweaver-Burk plots of the data shown in Figures $1 \mathrm{~d}$ and $5 \mathrm{~d}$. The lines represent fits with linear functions. The data are represented as mean \pm s.e.m. The n numbers are the same as in the original figures.

\section{Discussion}

Extracellular ATP is a key signaling molecule for the physiology of the airway epithelium as it mediates responses such as the increase of ciliary beat frequency and mucus production and triggers the cough reflex. Moreover, ATP is a key messenger of cellular damage and its detection plays a key role in activating protective mechanisms in neighboring healthy cells. Therefore, an insufficient ability to trigger a full response to ATP is expected to lead to reduced protective responses. Previous studies have established the implication of ATP-mediated signaling upon exposure to nanomaterials, including silica. However, these have mainly reported the induction of ATP release upon long-term exposure, from 30-40 $\mathrm{min}$ [45][47] to several hours [44][63][64]. In contrast, the acute effects of the nanoparticles on ATP-mediated signaling, that is, on the response to ATP itself, remained to be investigated. To cover this information gap in this study we assessed the acute effects of $10 \mathrm{~nm}$ NPs on the responses of cultured human airway epithelial cells to ATP.

We used the 16HBE cell line, which has been referred to as an excellent model for studying ATP-induced intracellular $\mathrm{Ca}^{2+}$ transients in human airway epithelial cells [65]. Accordingly, we found these cells to respond consistently to extracellular application of ATP in the range between 0.3 to $100 \mu \mathrm{M}$. These responses had amplitudes that increased with the ATP concentration and displayed the typical morphology, with a fast upstroke 
phase followed by a biphasic decay [65]. We further found that cells responded to a first application of ATP with $\mathrm{Ca}^{2+}$ transients of normal amplitude in free extracellular $\mathrm{Ca}^{2+}$ solutions. This shows that in our experimental conditions $16 \mathrm{HBE}$ cells respond to ATP via activation of $\mathrm{P} 2 \mathrm{Y}$ receptors leading to $\mathrm{IP}_{3}$-induced $\mathrm{Ca}^{2+}$ release from intracellular stores via type $3 \mathrm{IP}_{3}$ receptors, as previously reported [65][66]. Interestingly, the second and third applications of ATP in $\mathrm{Ca}^{2+}$-free solution failed to evoke responses, which may be due to a strong depletion of the intracellular stores induced by the first ATP application. In turn, this indicates for a crucial importance of the replenishing mechanisms for the maintenance of the responsiveness for the repetitive stimulation with ATP in physiological conditions (in the presence of extracellular $\mathrm{Ca}^{2+}$ ). We indeed found that in the latter condition consecutive applications of ATP several minutes apart induced reproducible responses. This allowed us to assess the effects of NPs by comparing the amplitudes of the responses to ATP in the absence and in the presence of NPs in the same cells.

Using this experimental paradigm, we found that NPs reduce the response to ATP in a concentration dependent manner. This inhibitory effect was not only observed in the presence of the NPs, but also found to be stronger minutes after the removal of NPs from the extracellular solution. This demonstrates that the primary mechanism underlying the inhibition is not mediated by NPs acting from the extracellular side of the membrane. It could be envisaged that NPs inhibit the $\mathrm{Ca}^{2+}$ response by directly targeting components of the ATP signaling pathway. For instance, NPs may alter the mechanical properties of cellular membranes [38], and this could affect the function of ATP receptors. Furthermore, previous TEM studies have shown that NPs can be internalized via endocytosis through plasma membrane vesicles containing several nanoparticles and that this uptake process is accompanied by plasma membrane consumption and disruption [15]. This may lead to a decrease in the number of ATP receptors and to the formation of $\mathrm{Ca}^{2+}$-permeable pores in the plasma membrane, which in turn may explain the reduction of the responses to ATP and the NPs-induced increase in intracellular $\mathrm{Ca}^{2+}$, respectively.

However, the hypothesis considering that NPs directly target components of the ATP signaling pathway has a limitation. The cellular concentration of NPs and thereby any putative direct effect on a signaling component would be expected to decay, not to increase, upon washout. Thus, it remains difficult to explain why the concentration dependencies of the NPs action show a more potent effect on the ATP responses during washout than during the application of the particles. A more plausible explanation is that the NPs trigger an inhibitory mechanism that outlives and is further enhanced after the ceasing of the accumulation of the nanoparticles in the cellular compartments. In this direction, the increase in intracellular $\mathrm{Ca}^{2+}$ emerged as a candidate factor to be involved, as we observed that NPs induced such effect in a rather irreversible manner, in agreement with our previous report [30]. However, the experiments in which we used ionomycin revealed that cells undergoing severe intracellular $\mathrm{Ca}^{2+}$ overload were able to respond, albeit slower, to a first application of ATP. Thus, it seems that the increase in $\mathrm{Ca}^{2+}$ induced by the NPs is not the primary factor underlying the decrease in the responses to ATP.

Although our present experiments do not allow pinpointing a precise target of NPs action, they did let us conclude that NPs act via a non-competitive inhibitory mechanism. Thus, these particles may affect any of the elements of ATP signaling cascade that determine the maximal intracellular $\mathrm{Ca}^{2+}$ response, but do not act on any factors determining the sensitivity to ATP. For instance, NPs may decrease the number of ATP receptors available for activation at the plasma membrane and/or their maximal level of activation, but may not decrease their affinity for ATP. The latter is informative, as it indicates that NPs do not interfere with the binding and unbinding of ATP to and from P2Y receptors. Furthermore, because we assess the responses to ATP from the amplitude of the $\mathrm{Ca}^{2+}$ increase, none of the events that determine the sensitivity to ATP may be affected. Future experiments, complemented by mathematical modeling, may help discerning what elements of the pathway may be affected or not by the NPs. 
Another curious result was that the inhibitory effect of NPs appeared to reach a plateau at concentrations above around $10 \mu \mathrm{g} / \mathrm{ml}$, indicating that they are unable to inhibit the responses to ATP completely when applied at concentrations up to $100 \mu \mathrm{g} / \mathrm{ml}$. Interestingly, we previously found a qualitatively similar effect for the inhibition of TRPV4 in 16HBE cells, but the plateau for maximal inhibition was reached at concentrations higher than around $300 \mu \mathrm{g} / \mathrm{ml}$ [30]. The difference in the concentrations for reaching the plateau phase of the two effects suggests that a concentration-dependent change in properties of the NPs is not the cause of this phenomenon. Alternatively, NPs might affect differently distinct pools of receptors or other ATP pathway elements or the particles might not have the ability to fully abrogate their function.

A key aspect of our findings is that the NPs concentrations required for the inhibition of the responses to ATP $(1-3 \mu \mathrm{g} / \mathrm{ml})$ are much lower than those needed to induce cytotoxicity or to observe cytokine release in vitro $(25-6000 \mu \mathrm{g} / \mathrm{ml})$ [67][68][69]. Furthermore, the time scale for the effects we report here is between 3- to 150-fold shorter than that required for other NPs effects. This suggests that the ATP signaling pathway is a primary and very sensitive target of NPs. Finally, it should be noted that the inhibitory action of NPs we report here and previously on TRPV4 are specific, as the same particles enhance the activation of the capsaicin receptor TRPV1 [30].

\section{Conclusions}

Our results demonstrate that silica NPs induce an acute non-competitive inhibition of the P2Y-mediated intracellular $\mathrm{Ca}^{2+}$ responses of cultured human airway epithelial cells to ATP. This effect occurs significantly faster and at concentrations lower than those previously reported for the induction of cellular toxicity and pro-inflammatory responses. Future research should be conducted to determine the molecular mechanisms of these actions, to test whether NPs are general inhibitors of purinergic signaling pathways in other cell types, and to determine whether NPs reduce the ability of airway epithelial cells to mount protective responses via the ATP signaling pathway, i.e. the increase in mucociliary clearance and cough.

\section{Materials and Methods}

\subsection{Ludox ${ }^{\circledR P S}$}

Silica nanoparticles used in this study were purchased from Sigma-Aldrich (Bornem, Belgium) as the commercial source of $30 \% \mathrm{wt}$ suspension in water. They are approximately $10.2 \mathrm{~nm}$ in diameter and have a Zeta-potential of $-20 \pm 3 \mathrm{mV}$. The complete characterization has been performed in previous studies by our group [30]. For the experiments, the nanoparticle suspension has been diluted to the desired concentrations in Krebs solution containing (in $\mathrm{mM}$ ): $150 \mathrm{NaCl}, 6 \mathrm{KCl}, 1 \mathrm{MgCl}$, $1.5 \mathrm{CaCl}_{2}, 10$ glucose, 10 4-(2-hydroxyethyl)-1-piperazineethanesulfonic acid (HEPES) and titrated to $\mathrm{pH} 7.4$ with $\mathrm{NaOH}$. The concentrations used are (in $\mu \mathrm{g} / \mathrm{ml}$ ): 1, 3, 10, 30, 100, 300.

\subsection{Cell culture}

Human bronchial epithelial cells (16HBE) were grown in Dulbecco's modified Eagle's medium: nutrient mixture F-12 (DMEM/F-12) containing 5\% (v/v) fetal calf serum (FCS), $2 \mathrm{mM}$ L-glutamine, $2 \mathrm{U} / \mathrm{ml}$ penicillin and $2 \mathrm{mg} / \mathrm{ml}$ streptomycin at $37{ }^{\circ} \mathrm{C}$ in humidified-controlled incubator with $5 \% \mathrm{CO}_{2}$ and were seeded on $18 \mathrm{~mm}$ cover slips coated with $0.1 \mathrm{mg} / \mathrm{ml}$ poly-L-lysine.

\subsection{Ratiometric intracellular $\mathrm{Ca}^{2+}$ imaging}

$\mathrm{Ca}^{2+}$-imaging experiments were conducted with the ratiometric fluorescent dye Fura-2 AM ester (Biotium, Hayward, CA, USA) as an indicator for free intracellular calcium. Cells were incubated with $2 \mu \mathrm{l} \mathrm{Fura-2}$ for $30 \mathrm{~min}$ at $37^{\circ} \mathrm{C}$. Solutions were applied 
using a multi-barrel perfusion system. The intracellular $\left[\mathrm{Ca}^{2+}\right]$ was calculated from the ratio of fluorescence measured upon alternating illumination at 340 and $380 \mathrm{~nm}$. Experiments were performed using an inverted microscope with MT-10 illumination system and the xcellence pro software of the microscope (Olympus, Planegg, Germany). All measurements have been performed at $35^{\circ} \mathrm{C}$. Fluorescence intensities were corrected for background signal and intracellular $\mathrm{Ca}^{2+}$ concentrations were calculated as described previously [70]. Data were analyzed and displayed using Origin (OriginLab Corporation).

\subsection{Data and statistical analysis}

To determine the amplitude of the response induced by the compounds of interest, we subtracted the baseline $\left[\mathrm{Ca}^{2+}\right]$ prior to the application from the peak value reached during challenging (value denoted by $\Delta\left[\mathrm{Ca}^{2+}\right]$ ). The baseline has been calculated by determining the mean $\left[\mathrm{Ca}^{2+}\right]$ during the last 20 seconds before the application of the compound. Data are given as \pm standard error of the mean.

\subsection{Reagents}

All chemicals were purchased from Sigma-Aldrich (Bornem, Belgium). The solutions containing the purines have been obtained from a $50 \mathrm{mM}$ ATP stock solution by diluting it with Krebs to obtain the desired concentrations (in $\mu \mathrm{M}$ ): 1, 3, 10, 30, 100. Ionomycin, an ionophore that triggers $\mathrm{Ca}^{2+}$ influx, has been used to show that the effect observed during the application of NPs is not calcium-mediated and thus is a result of the interaction of NPs with subcellular structures. Ionomycin at $1 \mu \mathrm{M}$ concentration has been obtained by dilution of $2 \mathrm{mM}$ stock in Krebs. Solutions used in measurements performed in the absence of extracellular $\mathrm{Ca}^{2+}$ have been prepared with Krebs containing (in $\mathrm{mM}$ ): $150 \mathrm{NaCl}, 6 \mathrm{KCl}, 1 \mathrm{MgCl}_{2}, 10 \mathrm{mM}$ ethylene glycol-bis( $\beta$-aminoethyl ether)- $\mathrm{N}, \mathrm{N}, \mathrm{N}^{\prime}, \mathrm{N}^{\prime}$-tetraacetic acid (EGTA), 10 glucose, 10 HEPES and titrated to $\mathrm{pH} 7.4$ with $\mathrm{NaOH}$.

Author Contributions: A.M., A.S. and K.T. conceived and designed all experiments. A.M. and A.S. performed the experiments. A.M., A.S. and K.T. analyzed the data. K.T. contributed to the funding. A.S. and K.T. supervised the project. A.M. and K.T. wrote the manuscript. All authors have read and agreed to the published version of the manuscript.

Funding: This research was supported by grants from the Research Foundation Flanders FWO (G076714) and by the Research Council of the KU Leuven (GOA/14/011). A.M. is funded by Erasmus+ 2019 - 2021 of the European Commission (KA 103-061892).

Institutional Review Board Statement: Not applicable.

Informed Consent Statement: Not applicable.

Acknowledgments: The authors thank Melissa Benoit for the maintenance of the cell cultures.

Conflicts of Interest: The authors declare no conflict of interest.

\section{References}

[1] W.G. Kreyling, M. Semmler-Behnke, Q. Chaudhry, A complementary definition of nanomaterial, Nano Today. 5 (2010). https://doi.org/10.1016/j.nantod.2010.03.004.

[2] E.A.J. Bleeker, W.H. de Jong, R.E. Geertsma, M. Groenewold, E.H.W. Heugens, M. Koers-Jacquemijns, D. van de Meent, J.R. Popma, A.G. Rietveld, S.W.P. Wijnhoven, F.R. Cassee, A.G. Oomen, Considerations on the EU definition of a nanomaterial: Science to support policy making, Regul. Toxicol. Pharmacol. 65 (2013). https://doi.org/10.1016/j.yrtph.2012.11.007.

[3] M. Naito, T. Yokoyama, K. Hosokawa, K. Nogi, Nanoparticle Technology Handbook, 2018. https://doi.org/10.1016/s1748-0132(07)70119-6. 
[4] D. Liu, N. Gu, Nanomaterials for Fresh-Keeping and Sterilization in Food Preservation, Recent Patents Food, Nutr. Agric. 1 (2012). https://doi.org/10.2174/2212798410901020149.

[5] Z. Fan, L. Zhang, W. Di, K. Li, G. Li, D. Sun, Methyl-grafted silica nanoparticle stabilized water-in-oil Pickering emulsions with low-temperature stability, J. Colloid Interface Sci. 588 (2021). https://doi.org/10.1016/j.jcis.2020.12.095.

[6] M. Qhobosheane, S. Santra, P. Zhang, W. Tan, Biochemically functionalized silica nanoparticles, Analyst. 126 (2001). https://doi.org/10.1039/b101489g.

[7] S. Murugadoss, D. Lison, L. Godderis, S. Van Den Brule, J. Mast, F. Brassinne, N. Sebaihi, P.H. Hoet, Toxicology of silica nanoparticles: an update, Arch. Toxicol. 91 (2017). https://doi.org/10.1007/s00204-017-1993-y.

[8] J. Wang, C. Asbach, H. Fissan, T. Hülser, T.A.J. Kuhlbusch, D. Thompson, D.Y.H. Pui, How can nanobiotechnology oversight advance science and industry: Examples from environmental, health, and safety studies of nanoparticles (nano-EHS), J. Nanoparticle Res. 13 (2011). https://doi.org/10.1007/s11051-011-0236-z.

[9] V. Vishwakarma, S.S. Samal, N. Manoharan, Safety and Risk Associated with Nanoparticles - A Review, J. Miner. Mater. Charact. Eng. 09 (2010). https://doi.org/10.4236/jmmce.2010.95031.

[10] V. Dubes, T. Parpaite, T. Ducret, J.F. Quignard, S. Mornet, N. Reinhardt, I. Baudrimont, M. Dubois, V. Freund-Michel, R. Marthan, B. Muller, J.P. Savineau, A. Courtois, Calcium signalling induced by in vitro exposure to silicium dioxide nanoparticles in rat pulmonary artery smooth muscle cells, Toxicology. 375 (2017) 37-47. https://doi.org/10.1016/j.tox.2016.12.002.

[11] Y.N. Zhang, W. Poon, A.J. Tavares, I.D. McGilvray, W.C.W. Chan, Nanoparticle-liver interactions: Cellular uptake and hepatobiliary elimination, J. Control. Release. 240 (2016). https://doi.org/10.1016/j.jconrel.2016.01.020.

[12] Z. Du, D. Zhao, L. Jing, G. Cui, M. Jin, Y. Li, X. Liu, Y. Liu, H. Du, C. Guo, X. Zhou, Z. Sun, Cardiovascular toxicity of different sizes amorphous silica nanoparticles in rats after intratracheal instillation, Cardiovasc. Toxicol. 13 (2013). https://doi.org/10.1007/s12012-013-9198-y.

[13] K. Mortezaee, M. Najafi, H. Samadian, H. Barabadi, A. Azarnezhad, A. Ahmadi, Redox interactions and genotoxicity of metal-based nanoparticles: A comprehensive review, Chem. Biol. Interact. $312 \quad$ (2019). https://doi.org/10.1016/j.cbi.2019.108814.

[14] L. Sun, Y. Li, X. Liu, M. Jin, L. Zhang, Z. Du, C. Guo, P. Huang, Z. Sun, Cytotoxicity and mitochondrial damage caused by silica nanoparticles, Toxicol. Vitr. 25 (2011). https://doi.org/10.1016/j.tiv.2011.06.012.

[15] C. Messerschmidt, D. Hofmann, A. Kroeger, K. Landfester, V. Mailänder, I. Lieberwirth, On the pathway of cellular uptake: New insight into the interaction between the cell membrane and very small nanoparticles, Beilstein J. Nanotechnol. 7 (2016). https://doi.org/10.3762/bjnano.7.121.

[16] M. Geiser, B. Rothen-Rutishauser, N. Kapp, S. Schürch, W. Kreyling, H. Schulz, M. Semmler, V. Im Hof, J. Heyder, P. Gehr, Ultrafine particles cross cellular membranes by nonphagocytic mechanisms in lungs and in cultured cells, Environ. Health Perspect. 113 (2005). https://doi.org/10.1289/ehp.8006.

[17] S. Zhang, H. Gao, G. Bao, Physical Principles of Nanoparticle Cellular Endocytosis, ACS Nano. 9 (2015). https://doi.org/10.1021/acsnano.5b03184.

[18] G.B. Hamra, N. Guha, A. Cohen, F. Laden, O. Raaschou-Nielsen, J.M. Samet, P. Vineis, F. Forastiere, P. Saldiva, T. Yorifuji, D. Loomis, Outdoor particulate matter exposure and lung cancer: A systematic review and meta-analysis, Environ. Health Perspect. 122 (2014). https://doi.org/10.1289/ehp.1408092.

[19] T. Xia, M. Kovochich, J. Brant, M. Hotze, J. Sempf, T. Oberley, C. Sioutas, J.I. Yeh, M.R. Wiesner, A.E. Nel, Comparison of the abilities of ambient and manufactured nanoparticles to induce cellular toxicity according to an oxidative stress paradigm, Nano Lett. 6 (2006). https://doi.org/10.1021/nl061025k.

[20] J.J. Corbalan, C. Medina, A. Jacoby, T. Malinski, M.W. Radomski, Amorphous silica nanoparticles trigger nitric oxide/peroxynitrite imbalance in human endothelial cells: inflammatory and cytotoxic effects., Int. J. Nanomedicine. 6 
(2011). https://doi.org/10.2147/ijn.s25071.

[21] Y. Liu, E. Yoo, C. Han, G.J. Mahler, A.L. Doiron, Endothelial barrier dysfunction induced by nanoparticle exposure through actin remodeling via caveolae/raft-regulated calcium signalling, NanoImpact. $11 \quad$ (2018). https://doi.org/10.1016/j.impact.2018.02.007.

[22] E.Y. Chen, M. Garnica, Y.C. Wang, A.J. Mintz, C.S. Chen, W.C. Chin, A mixture of anatase and rutile TiO2nanoparticles induces histamine secretion in mast cells, Part. Fibre Toxicol. 9 (2012). https://doi.org/10.1186/1743-8977-9-2.

[23] S.T. Selvan, T.T. Yang Tan, D. Kee Yi, N.R. Jana, Functional and multifunctional nanoparticles for bioimaging and biosensing, Langmuir. 26 (2010). https://doi.org/10.1021/la903512m.

[24] K.I. Lee, C.C. Su, K.M. Fang, C.C. Wu, C.T. Wu, Y.W. Chen, Ultrafine silicon dioxide nanoparticles cause lung epithelial cells apoptosis via oxidative stress-activated PI3K/Akt-mediated mitochondria- and endoplasmic reticulum stress-dependent signaling pathways, Sci. Rep. 10 (2020). https://doi.org/10.1038/s41598-020-66644-z.

[25] A.M. Marchiando, W.V. Graham, J.R. Turner, Epithelial barriers in homeostasis and disease, Annu. Rev. Pathol. Mech. Dis. 5 (2010). https://doi.org/10.1146/annurev.pathol.4.110807.092135.

[26] S. Ganesan, A.T. Comstock, U.S. Sajjan, Barrier function of airway tract epithelium, Tissue Barriers. 1 (2013). https://doi.org/10.4161/tisb.24997.

[27] M. Legendre, L.E. Zaragosi, H.M. Mitchison, Motile cilia and airway disease, Semin. Cell Dev. Biol. 110 (2021). https://doi.org/10.1016/j.semcdb.2020.11.007.

[28] R.J. Hewitt, C.M. Lloyd, Regulation of immune responses by the airway epithelial cell landscape, Nat. Rev. Immunol. (2021). https://doi.org/10.1038/s41577-020-00477-9.

[29] M.W. Fariss, M.I. Gilmour, C.A. Reilly, W. Liedtke, A.J. Ghio, Emerging mechanistic targets in lung injury induced by combustion-generated particles, Toxicol. Sci. 132 (2013) 253-267. https://doi.org/10.1093/toxsci/kft001.

[30] A. Sanchez, J.L. Alvarez, K. Demydenko, C. Jung, Y.A. Alpizar, J. Alvarez-Collazo, S.M. Cokic, M.A. Valverde, P.H. Hoet, K. Talavera, Silica nanoparticles inhibit the cation channel TRPV4 in airway epithelial cells, Part. Fibre Toxicol. 14 (2017). https://doi.org/10.1186/s12989-017-0224-2.

[31] H. Yu, Q. Li, V.P. Kolosov, J.M. Perelman, X. Zhou, Regulation of particulate matter-induced mucin secretion by transient receptor potential vanilloid 1 receptors, Inflammation. 35 (2012) 1851-1859. https://doi.org/10.1007/s10753-012-9506-x.

[32] T.A. Memon, N.D. Nguyen, K.L. Burrell, A.F. Scott, M. Almestica-Roberts, E. Rapp, C.E. Deering-Rice, C.A. Reilly, Wood Smoke Particles Stimulate MUC5AC Overproduction by Human Bronchial Epithelial Cells Through TRPA1 and EGFR Signaling, Toxicol. Sci. 174 (2020) 278-290. https://doi.org/10.1093/toxsci/kfaa006.

[33] B.G. Kim, M.K. Park, P.H. Lee, S.H. Lee, J. Hong, M.M.M. Aung, K.T. Moe, N.Y. Han, A.S. Jang, Effects of nanoparticles on neuroinflammation in a mouse model of asthma, Respir. Physiol. Neurobiol. 271 (2020). https://doi.org/10.1016/j.resp.2019.103292.

[34] D. Shapiro, C.E. Deering-Rice, E.G. Romero, R.W. Hughen, A.R. Light, J.M. Veranth, C.A. Reilly, Activation of transient receptor potential ankyrin-1 (TRPA1) in lung cells by wood smoke particulate material, Chem. Res. Toxicol. 26 (2013) 750758. https://doi.org/10.1021/tx400024h.

[35] F. Piccinno, F. Gottschalk, S. Seeger, B. Nowack, Industrial production quantities and uses of ten engineered nanomaterials in Europe and the world, J. Nanoparticle Res. 14 (2012). https://doi.org/10.1007/s11051-012-1109-9.

[36] P.N. Breysse, Toxicological profile for silica, 2019.

[37] A. Gilardino, F. Catalano, F.A. Ruffinatti, G. Alberto, B. Nilius, S. Antoniotti, G. Martra, D. Lovisolo, Interaction of SiO2 nanoparticles with neuronal cells: Ionic mechanisms involved in the perturbation of calcium homeostasis, Int. J. Biochem. Cell Biol. 66 (2015) 101-111. https://doi.org/10.1016/j.biocel.2015.07.012.

[38] X. Wei, W. Jiang, J. Yu, L. Ding, J. Hu, G. Jiang, Effects of SiO2 nanoparticles on phospholipid membrane integrity and fluidity, J. Hazard. Mater. 287 (2015). https://doi.org/10.1016/j.jhazmat.2015.01.063. 
[39] P. Ariano, P. Zamburlin, A. Gilardino, R. Mortera, B. Onida, M. Tomatis, M. Ghiazza, B. Fubini, D. Lovisolo, Interaction of spherical silica nanoparticles with neuronal cells: Size-dependent toxicity and perturbation of calcium homeostasis, Small. 7 (2011). https://doi.org/10.1002/smll.201002287.

[40] N. Sharma, S. Jha, Amorphous nanosilica induced toxicity, inflammation and innate immune responses: A critical review, Toxicology. 441 (2020). https://doi.org/10.1016/j.tox.2020.152519.

[41] C. Distasi, M. Dionisi, F.A. Ruffinatti, A. Gilardino, R. Bardini, S. Antoniotti, F. Catalano, E. Bassino, L. Munaron, G. Martra, D. Lovisolo, The interaction of $\mathrm{SiO} 2$ nanoparticles with the neuronal cell membrane: Activation of ionic channels and calcium influx, Nanomedicine. 8 (2019). https://doi.org/10.2217/nnm-2018-0256.

[42] A. Milici, K. Talavera, Trp channels as cellular targets of particulate matter, Int. J. Mol. Sci. 22 (2021). https://doi.org/10.3390/ijms22052783.

[43] S. Dekali, A. Divetain, T. Kortulewski, J. Vanbaelinghem, C. Gamez, F. Rogerieux, G. Lacroix, P. Rat, Cell cooperation and role of the P2X7 receptor in pulmonary inflammation induced by nanoparticles, Nanotoxicology. 7 (2013). https://doi.org/10.3109/17435390.2012.735269.

[44] S. Kojima, Y. Negishi, M. Tsukimoto, T. Takenouchi, H. Kitani, K. Takeda, Purinergic signaling via P2X7 receptor mediates IL-1 $\beta$ production in Kupffer cells exposed to silica nanoparticle, Toxicology. $321 \quad$ (2014). https://doi.org/10.1016/j.tox.2014.03.008.

[45] C. Nagakura, Y. Negishi, M. Tsukimoto, S. Itou, T. Kondo, K. Takeda, S. Kojima, Involvement of P2Y11 receptor in silica nanoparticles 30-induced IL-6 production by human keratinocytes, Toxicology. $322 \quad$ (2014). https://doi.org/10.1016/j.tox.2014.03.010.

[46] F. Hofmann, R. Bläsche, M. Kasper, K. Barth, A co-culture system with an organotypic lung slice and an immortal alveolar macrophage cell line to quantify silica-induced inflammation, PLoS One. $10 \quad$ (2015). https://doi.org/10.1371/journal.pone.0117056.

[47] K. Nakanishi, M. Tsukimoto, S. ichi Tanuma, K. Takeda, S. Kojima, Silica nanoparticles activate purinergic signaling via P2X7 receptor in dendritic cells, leading to production of pro-inflammatory cytokines, Toxicol. Vitr. 35 (2016). https://doi.org/10.1016/j.tiv.2016.06.003.

[48] K. Braun, C.M. Stürzel, J. Biskupek, U. Kaiser, F. Kirchhoff, M. Lindén, Comparison of different cytotoxicity assays for in vitro evaluation of mesoporous silica nanoparticles, Toxicol. Vitr. 52 (2018). https://doi.org/10.1016/j.tiv.2018.06.019.

[49] Z. Qi, K. Murase, S. Obata, M. Sokabe, Extracellular ATP-dependent activation of plasma membrane Ca2+ pump in HEK-293 cells, Br. J. Pharmacol. 131 (2000). https://doi.org/10.1038/sj.bjp.0703563.

[50] G.R. Dubyak, C. el-Moatassim, Signal transduction via P2-purinergic receptors for extracellular ATP and other nucleotides., Am. J. Physiol. 265 (1993). https://doi.org/10.1152/ajpcell.1993.265.3.c577.

[51] G. Burnstock, Historical review: ATP as a neurotransmitter, Trends Pharmacol. Sci. 27 (2006). https://doi.org/10.1016/j.tips.2006.01.005.

[52] V. Ralevic, G. Burnstock, Receptors for purines and pyrimidines, Pharmacol. Rev. 50 (1998). https://doi.org/10.1007/978-3-642-28863-0_5.

[53] C.L. Sherwood, R. Clark Lantz, S. Boitano, Chronic arsenic exposure in nanomolar concentrations compromises wound response and intercellular signaling in airway epithelial cells, Toxicol. Sci. 132 (2013). https://doi.org/10.1093/toxsci/kfs331.

[54] A. van der Vliet, P.F. Bove, Purinergic signaling in wound healing and airway remodeling, Subcell. Biochem. 55 (2015). https://doi.org/10.1007/978-94-007-1217-1_6.

[55] G. Burnstock, I. Brouns, D. Adriaensen, J.P. Timmermans, Purinergic signaling in the airways, Pharmacol. Rev. 64 (2012). https://doi.org/10.1124/pr.111.005389.

[56] G. Burnstock, Purinergic Signalling and Neurological Diseases: An Update, CNS Neurol. Disord. - Drug Targets. 16 (2017). https://doi.org/10.2174/1871527315666160922104848. 
[57] G. Burnstock, Purines and sensory nerves, Handb. Exp. Pharmacol. 194 (2009). https://doi.org/10.1007/978-3-540-79090-7_10.

[58] W. Fischer, K. Wirkner, M. Weber, C. Eberts, L. Köles, R. Reinhardt, H. Franke, C. Allgaier, C. Gillen, P. Illes, Characterization of P2X3, P2Y1 and P2Y4 receptors in cultured HEK293-hP2X3 cells and their inhibition by ethanol and trichloroethanol, J. Neurochem. 85 (2003). https://doi.org/10.1046/j.1471-4159.2003.01716.x.

[59] S. Vilotti, A. Marchenkova, N. Ntamati, A. Nistri, B-type natriuretic peptide-induced delayed modulation of TRPV1 and P2X3 Receptors of mouse trigeminal sensory neurons, PLoS One. 8 (2013). https://doi.org/10.1371/journal.pone.0081138.

[60] K. Droguett, M. Rios, D. V. Carreño, C. Navarrete, C. Fuentes, M. Villalón, N.P. Barrera, An autocrine ATP release mechanism regulates basal ciliary activity in airway epithelium, J. Physiol. 595 (2017). https://doi.org/10.1113/JP273996.

[61] E. Wirsching, M. Fauler, G. Fois, M. Frick, P2 purinergic signaling in the distal lung in health and disease, Int. J. Mol. Sci. 21 (2020). https://doi.org/10.3390/ijms21144973.

[62] M.A. Carew, M.L. Wu, G.J. Law, Y.Z. Tseng, W.T. Mason, Extracellular ATP activates calcium entry and mobilization via P2U-purinoceptors in rat lactotrophs, Cell Calcium. 16 (1994). https://doi.org/10.1016/0143-4160(94)90025-6.

[63] N. Riteau, L. Baron, B. Villeret, N. Guillou, F. Savigny, B. Ryffel, F. Rassendren, M. Le Bert, A. Gombault, I. Couillin, ATP release and purinergic signaling: A common pathway for particle-mediated inflammasome activation, Cell Death Dis. 3 (2012). https://doi.org/10.1038/cddis.2012.144.

[64] L. Baron, A. Gombault, M. Fanny, B. Villeret, F. Savigny, N. Guillou, C. Panek, M. Le Bert, V. Lagente, F. Rassendren, N. Riteau, I. Couillin, The NLRP3 inflammasome is activated by nanoparticles through ATP, ADP and adenosine, Cell Death Dis. 6 (2015). https://doi.org/10.1038/cddis.2014.576.

[65] I. Sienaert, S. Huyghe, J.B. Parys, M. Malfait, K. Kunzelman, H. De Smedt, G.M. Verleden, L. Missiaen, ATP-induced Ca2+ signals in bronchial epithelial cells, Pflugers Arch. Eur. J. Physiol. 436 (1998). https://doi.org/10.1007/s004240050602.

[66] D. Communi, P. Paindavoine, G.A. Place, M. Parmentier, J.M. Boeynaems, Expression of P2Y receptors in cell lines derived from the human lung, Br. J. Pharmacol. 127 (1999). https://doi.org/10.1038/sj.bjp.0702560.

[67] J. Kasper, M.I. Hermanns, C. Bantz, M. Maskos, R. Stauber, C. Pohl, R.E. Unger, J.C. Kirkpatrick, Inflammatory and cytotoxic responses of an alveolar-capillary coculture model to silica nanoparticles: Comparison with conventional monocultures, Part. Fibre Toxicol. 8 (2011). https://doi.org/10.1186/1743-8977-8-6.

[68] V. Rabolli, A.A. Badissi, R. Devosse, F. Uwambayinema, Y. Yakoub, M. Palmai-Pallag, A. Lebrun, V. De Gussem, I. Couillin, B. Ryffel, E. Marbaix, D. Lison, F. Huaux, The alarmin IL-1 $\alpha$ is a master cytokine in acute lung inflammation induced by silica micro- and nanoparticles, Part. Fibre Toxicol. 11 (2014). https://doi.org/10.1186/s12989-014-0069-x.

[69] T. Skuland, J. Øvrevik, M. Låg, P. Schwarze, M. Refsnes, Silica nanoparticles induce cytokine responses in lung epithelial cells through activation of a p38/TACE/TGF- $\alpha$ /EGFR-pathway and NF- $\kappa B$ signalling, Toxicol. Appl. Pharmacol. 279 (2014). https://doi.org/10.1016/j.taap.2014.05.006.

[70] G. Grynkiewicz, M. Poenie, R.Y. Tsien, A new generation of Ca2+ indicators with greatly improved fluorescence properties, J. Biol. Chem. 260 (1985). https://doi.org/10.1016/s0021-9258(19)83641-4. 